\title{
Genetic Assessment for Fruit Yield and Horticultural Traits in Bacterial Wilt Tolerant Genotypes of Bell Pepper (Capsicum annuum L. var. grossum Sendt.)
}

\author{
Anuradha* and Sonia Sood
}
Department of Vegetable Science and Floriculture, College of Agriculture, CSK Himachal Pradesh Krishi Vishvavidyalaya, Palampur (HP)-176 062, India

*Corresponding author

\begin{abstract}
A B S T R A C T
The present investigation was carried out with the objectives of getting information on the magnitude of genetic variability for quantitative and quality traits in the bacterial wilt tolerant genotypes of bell pepper (Capsicum annuиm L. var. grossum Sendt.). The experiment material consisted of 43 genotypes (39

Keywords

Bell pepper, Mean performance, PCV, GCV, Heritability, Genetic advance

Article Info

Accepted:

07 July 2019

Available Online:

10 August 2019 bacterial wilt tolerant genotypes, two resistant, one moderately resistant and one susceptible check) that were evaluated in Randomized Complete Block Design (RCBD) during summer-rainy season, 2018. Data were recorded on days to 50 per cent flowering, days to first picking, plant height $(\mathrm{cm})$, primary branches per plant, harvest duration (days), fruit length $(\mathrm{cm})$, fruit width $(\mathrm{cm})$, pericarp thickness $(\mathrm{mm})$, lobes per fruit, average fruit weight $(\mathrm{g})$, marketable fruits per plant, marketable fruit yield per plant $(\mathrm{g})$, capsanthin content (ASTA units), TSS ( ${ }^{\circ}$ Brix) and ascorbic acid content $(\mathrm{mg} / 100 \mathrm{~g})$. The analysis of variance revealed significant differences among genotypes for all quantitative and quality traits. Among all, genotypes DPCBWR-14-39 (541.44 g), DPCBWR-14-36 (510.30 g), DPCBWR-14-2 (448.93 g), DPCBWR-14-35 (424.34 g) and DPCBWR-14-29 (421.49 g) were the highest yielders and these were also among the top genotypes for economic traits viz., marketable fruits per plant and average fruit weight. The estimates of GCV were lower than the respective PCV, indicating the influence of environmental factors on the expression of the traits studied. The estimates of PCV and GCV were high for marketable fruits per plant, marketable fruit yield per plant and capsanthin content depicting the presence of substantial variability and would response better to selection. High heritability coupled with high genetic advance was observed for fruit length, marketable fruits per plant, marketable fruit yield per plant, capsanthin content and ascorbic acid revealing the importance of additive gene action and could be improved through direct selection.
\end{abstract}

\section{Introduction}

Bell pepper (Capsicum annuи L. var. grossum Sendt.), a member of family Solanaceae with chromosome number $2 n=24$ is popularly known as Sweet pepper or Capsicum or Shimla mirch. It is an important vegetable crop grown worldwide for its delicate taste, pleasant flavour and colour and is a leading crop under protected conditions. It is high value solanaceous vegetable and is an important cash crop for temperate and subtemperate regions. It is native to Mexico with secondary centre of origin in Guatemala (Bukasov, 1930). Bell pepper was introduced in India by the Britishers during the $19^{\text {th }}$ century in Shimla hills, hence popularly known as 'Shimla Mirch'. It is mostly consumed raw in green mature forms, cooked as vegetable or widely used in stuffings, pizza making, preparation of soups and stews for imparting flavor, aroma and colour. Besides 
its use as a food ingredient, also used traditionally in ailments such as stomach ache, diarrhea and dysentery. It lowers blood cholesterol level, improves blood circulation, boosts immune system and relieves arthritic pain (Thakur et al., 2019). However, it is also recommended in cases of diabetes, Alzheimer's and Parkinson's diseases (Hasler, 1998 and Rios et al., 2013). Bell pepper is an excellent source of various nutrients and vitamins like provitamin $\mathrm{A}$ ( $\beta$-carotene) and vitamin $C$, which may be present up to 340 $\mathrm{mg} / 100 \mathrm{~g}$ in some of its varieties (Purseglove et al., 1981). Presently, it is commercially grown in Himachal Pradesh, Jammu and Kashmir, Uttrakhand, Arunachal Pradesh and Darjeeling district of West Bengal during summer months and as an autumn crop in Maharashtra, Karnataka, Tamil Nadu and Bihar. Some areas cultivate the fruits yearround in greenhouses, including Pune, Bangalore and Karnataka, whereas on a limited scale in the states of Kerala, Andhra Pradesh, West Bengal, Gujarat, and Goa.

In Himachal Pradesh, it enjoys the status of off-season vegetable, as during summer-rainy season large quantity of capsicum is transported to the distant markets in the plain areas which bring a boost in the economic conditions of the small and marginal farmers of the state. Mid hills of the state are leading suppliers of fresh market bell pepper. This produce is not only off-season for market in the plains, but is of excellent quality mainly because of genotype $x$ environment interaction which produces big size blocky fruits with high flavour and shiny skin (Singh et al., 2018). Inspite of its importance a few varieties are grown commercially. The yield potential and total production of capsicum is low due to poor yielding varieties and high incidence of diseases and pests. Among diseases, bacterial wilt caused by Ralstonia solanacearum is one of the most important diseases in humid tropical and sub-tropical areas causing huge losses. The available varieties of bell pepper are highly susceptible to bacterial wilt. Hence, there is a need for the identification and development of improved disease resistant varieties to boost up the production and productivity of the crop in wilt prone areas of HP as well as other parts of the country.

The potential for improvement in any crop is directly related to the magnitude of variability present in the germplasm (Kumari, 2013). In sweet pepper, a wide range of variability is available, which provides possibilities to improve fruit yield through a breeding programme. When variability is partitioned into heritable and non-heritable components, efficiency of selection is better understood. Response to selection depends on the relative proportion of the heritable component in the continuous variation. The heritable component is due to genotype, whereas the non-heritable portion is mainly due to environmental factors. Assessment of genotypes is possible through assessment of phenotypic expression, the results of genotype, and the environmental expression. Heritability and genetic advance help in determining the influence of the environment in the expression of the characters and extent to which improvement is possible through selection (Robinson et al., 1949). Higher the heritable variation, greater will be the possibility of fixing the characters by selection methods. Therefore, the present investigation was carried to assess the genetic variability for important quantitative and quality traits for genetic improvement of bell pepper.

\section{Materials and Methods}

The present investigation was undertaken at the Experimental Farm of Department of Vegetable Science and Floriculture, Chaudhary Sarwan Kumar Himachal Pradesh Krishi Vishvavidyalaya, Palampur from February-July, 2018. 


\section{Experimental site}

\section{Location}

The Experimental Farm is situated at $32^{\circ} 6^{\prime} \mathrm{N}$ latitude, $76^{\circ} 3^{\prime} \mathrm{E}$ longitude under mid hill zone of Himachal Pradesh at Palampur at an elevation of $1290.8 \mathrm{~m}$ above mean sea level.

\section{Climate}

The place experiences severe winters and mild summers. Agro-climatically, the location represents mid-hill zone of Himachal Pradesh (Zone-II) and is characterized by humid subtemperate climate with high annual rainfall $(2500 \mathrm{~mm})$ of which 80 per cent is received during June to September.

\section{Soil}

The soil of the experimental block was acidic in nature with $\mathrm{pH}$ ranging from 5.0 to 5.6 and soil texture was silty clay loam.

\section{Experimental material}

The experimental material comprised of 43 genotypes of bell pepper of which 39 were advanced breeding lines derived from different inter-varietal crosses. These genotypes were evaluated along with susceptible check (California Wonder), moderately resistant check (Kandaghat Selection) and two resistant checks (EC464107 and EC-464115) as per the details given in Table 2.

\section{Nursery sowing}

The nursery was sown on $8^{\text {th }}$ February, 2018 for summer- rainy season crop in plastic protrays at the Vegetable Research Farm of CSK Himachal Pradesh Krishi Vishvavidyalaya, Palampur. Before sowing, the seeds were treated with Bavistin and Dithane M-45 as a prophylactic measures against fungal pathogens.

\section{Experimental layout and transplanting}

The seedlings of 39 bacterial wilt tolerant genotypes along with one moderately resistant, two resistant checks and one susceptible check were transplanted in Randomized Complete Block Design (RCBD) with three replications on $3^{\text {rd }}$ April, 2018. Each entry/genotype accommodated 12 plants per replication with inter and intra row spacing of $60 \mathrm{~cm}$ and $45 \mathrm{~cm}$, respectively. The experimental field was prepared by ploughing 3-4 times with power tiller upto a depth of 20 $\mathrm{cm}$ followed by leveling. The farm yard manure was applied at the rate of $20 \mathrm{t} / \mathrm{ha}$, the chemical fertilizers were applied as per the recommended package of practices $(90 \mathrm{Kg} \mathrm{N}$, $75 \mathrm{Kg} \mathrm{P}_{2} \mathrm{O}_{5}$ and $50 \mathrm{Kg} \mathrm{K}_{2} \mathrm{O} / \mathrm{ha}$ ). One-third dose of $\mathrm{N}$ and full doses of FYM, $\mathrm{P}_{2} \mathrm{O}_{5}$ and $\mathrm{K}_{2} \mathrm{O}$ were applied at the time of field preparation. Remaining two third dose of $\mathrm{N}$ was top dressed in two equal amounts after 30 and 45 days of transplanting. The data were recorded on five randomly selected plants for days to 50 per cent flowering, days to first picking, plant height $(\mathrm{cm})$, primary branches per plant, harvest duration (days), fruit length $(\mathrm{cm})$, fruit width $(\mathrm{cm})$, pericarp thickness $(\mathrm{mm})$, lobes per fruit, average fruit weight $(\mathrm{g})$, marketable fruits per plant and marketable fruit yield per plant (g).

Capsanthin content (ASTA units) from the ripened fruit sample was estimated by the method as described by AOAC (1980). Total Soluble Solids ( ${ }^{\circ}$ Brix) was estimated by Hand Refractometer. Ascorbic acid content (mg/100g fresh weight) from the crushed fruit sample was estimated by the method as described by Ranganna (1977). The mean values of the data collected were used for analysis of variance (Table 3) for RCBD was estimated (Panse and Sukhtame, 1984). The 
phenotypic, genotypic and environmental coefficients of variation were estimated following Burton and De Vane (1953) as follows:

Phenotypic coefficient of variation $(\mathrm{PCV}) \%=\frac{\sigma \mathrm{p}}{\overline{\mathrm{X}}} \times 100$ Genotypic coefficient of variation (GCV) $\%=\frac{\sigma g}{\overline{\mathrm{X}}} \times 100$

Where, $\sigma p, \sigma g$ and $\bar{X}$ are phenotypic standard deviation, genotypic standard deviation and grand mean, respectively.

Heritability in broad sense $\left(\mathrm{h}^{2} \mathrm{bs}\right)$ was calculated as per the following formula given by Burton and De Vane (1953) and Johnson et al., (1955).

Heritability $\left(h^{2}{ }_{b s}\right)=\frac{\sigma^{-} g}{\sigma^{2} g+\sigma^{2} e} \times 100$

Where, $\sigma^{2} \mathrm{~g}, \sigma^{2} \mathrm{e}$ and $\sigma^{2} \mathrm{~g}+\sigma^{2} \mathrm{e}$ are genotypic variance, environmental variance and phenotypic variances, respectively.

The expected genetic advance (GA) resulting from the selection of $5 \%$ superior individuals was calculated as per Burton and De Vane (1953) and Johnson et al., (1955).

$\mathrm{GA}=\mathrm{K} \cdot \sigma \mathrm{p} \cdot \mathrm{h}_{\mathrm{bs}}^{2}$

Where, $\mathrm{K}=2.06$ (selection differential at $5 \%$ selection intensity), $\sigma p=$ phenotypic standard deviation and $h^{2} b s=$ heritability (broad sense), respectively.

Genetic advance as percentage of mean (GA Expected GA

$\%)=$ Grand mean $\times 100$

Limits used for categorizing the magnitude of different parameters are presented in Table 1.

\section{Statistical analysis}

The mean values of different genotypes for various traits were statistically analysed using OPSTAT programme. OPSTAT (developed by CCS Haryana Agricultural University, Hisar, India) software was used for statistical analysis.

\section{Results and Discussion}

\section{Analysis of Variance}

The mean sum of squares due to genotypes showed significant differences for all the characters studied among 43 genotypes, including checks (Table 3), indicating the presence of high genetic variability among the genotypes. The significant differences among the genotypes studied suggest that variability can be further utilized in bell pepper improvement programme. Earlier workers Ahmed et al., (2012), Afroza et al., (2013b), Kumari (2013), Pandey et al., (2013), Cebula et al., (2015), Rana et al., (2015), Sharma et al., (2017), Thakur et al., (2017), Aditika et al., (2018), Esho (2018), Singh et al., (2018) and Thakur et al., (2019) have also reported variability in their respective genetic material of bell pepper. The extent of variability present in the bell pepper genotypes was measured in terms of mean, range, phenotypic (PCV) and genotypic (GCV) coefficients of variation, heritability (broad sense), genetic advance as per cent of mean for all the traits are presented in Tables 4 and 5.

\section{Mean Performance of Genotypes}

Mean performance of different genotypes for various traits along with ranges, grand means, standard errors, coefficients of variation and critical differences are given in Table 4. Days to 50 per cent flowering and first picking are the traits which determine the earliness of a variety and consequently help in capturing 
early market which fetches high price in markets, whereas fruits per plant, fruit length, fruit width and weight are the major yield contributing traits. Based on mean values, genotypes viz., DPCBWR-14-39 (34.50 days), DPCBWR-14-32 (35.00 days), DPCBWR-1429 (36.67 days) and DPCBWR-14-7 (37.67 days) were early in 50 per cent flowering and genotypes viz., DPCBWR-14-29 (51.00 days) and DPCBWR-14-39 (52.00 days) took less number of days to first picking. The results are in conformity with the findings of Sharma et al., (2010), Sharma et al., (2013), Rana et al., (2015), Sharma et al., (2017), Esho (2018) and Thakur et al., (2019) for days to 50 per cent flowering, whereas Sood et al., (2011), Afroza et al., (2013b), Sharma (2014), Sharma et al., (2017) and Thakur et al., (2019) for days to first picking.

Bell pepper is grown in the low and mid hills of Himachal Pradesh during rainy season, where taller plants are preferred to prevent the diseases, besides ensuring fruiting over a longer period of time. In the present study, maximum plant height was found in DPCBWR-14-5 $(70.00 \mathrm{~cm})$ followed by DPCBWR-14-11(BS) (68.33 cm). More primary branches per plant are preferred for getting more fruits per plant and ultimately higher marketable fruit yield. DPCBWR-1440 (3.83) had maximum number of primary branches per plant followed by L-4 (3.70). These results are in broad confirmity with the findings of Sharma et al., (2013), Rana et al., (2015), Sharma et al., (2017), Esho (2018) and Thakur et al., (2019) for both plant height and primary branches per plant.

Genotypes having longer harvest duration are generally preferred in the present marketing system under Indian conditions because it not only avoids the glut in the market but also maintained off-season value of the crop. Genotypes with long harvest duration, in general, produced more fruits and high fruit yield per plant. In the present study genotype DPCBWR-14-39 offered promise for more marketable fruits per plant (15.33) and marketable fruit yield per plant (541.44 g) and thus suitable for long harvest duration (49.67 days). Similar findings were also reported by Sood et al., (2009), Sood et al., (2011), Devi et al., (2015), Sharma et al., (2017) and Thakur et al., (2019).

In present market, medium sized blocky fruits are preferred over large sized fruits. Among genotypes, DPCBWR-14-14 had maximum fruit length $(6.50 \mathrm{~cm})$ followed by DPCBWR$14-23(6.43 \mathrm{~cm})$. These genotypes had fruit width of 4.37 and $4.16 \mathrm{~cm}$; and pericarp thickness of 3.27 and $3.57 \mathrm{~mm}$, respectively. Fruit width is a desirable trait for obtaining blocky fruits and DPCBWR-14-20 $(4.92 \mathrm{~cm})$ excelled for fruit width followed by L-22 $(4.88 \mathrm{~cm})$. Pericarp thickness is an important parameter which is suitable for long storage and distance transportation. Among the genotypes, DPCBWR-14-6-1 (5.13 mm) exerted maximum pericarp thickness followed by DPCBWR-14-22 (4.70 mm). DPCBWR14-9 (4.11) excelled for lobes per fruit, whereas in all the genotypes a narrow range of lobes per fruit (2.17 to 4.11) was observed. Earlier workers Islam and Singh (2006), Rana et al., (2015), Sharma et al., (2013), Sharma (2014), Sharma et al., (2017) and Thakur et al., (2019) also reported similar results.

Higher fruit yield is the prime objective of all the crop improvement programmes. The genotypes DPCBWR-14-39 (541.44 g), DPCBWR-14-36 (510.30 g), DPCBWR-14-2 (448.93 g), DPCBWR-14-35 (424.34 g) and DPCBWR-14-29 (421.49 g) were the highest yielders (Table 4 and 6). These genotypes were also among the top genotypes for other economic traits viz., marketable fruits per plant, average fruit weight and plant survival. The higher yield obtained in these genotypes were mainly on account of inherent ability to 
produce more marketable fruits per plant, harvest duration, early flowering and picking, which were the main component traits contributed towards increased fruit yield. In general, fruits per plant are an important parameter which directly influences the yield. Maximum marketable fruits per plant (16.07) were harvested from DPCBWR-14-36. The highest average fruit weight was obtained from DPCBWR-14-14 (46.08 g) followed by DPCBWR-14-1 (44.07 g) and DPCBWR-14$17(43.02 \mathrm{~g})$. These results are in close confirmity with the findings of Sood et al., (2011), Kumari (2013), Sharma et al., (2013), Devi et al., (2015), Rana et al., (2015), Sharma et al., (2017) and Thakur et al., (2019).

Among the quality traits, maximum capsanthin and ascorbic acid were recorded in DPCBWR-14-32 and DPCBWR-14-3 (149.53 ASTA units and $138.04 \mathrm{mg} / 100 \mathrm{~g}$ ), respectively. DPCBWR-14-32 was the only genotype with good amount of both quality traits viz., capsanthin (149.53 ASTA units) and ascorbic acid (109.18 mg/100g).

Capsanthin is a neutral pigment gains great attention because it is used worldwide in the food, cosmetic and dye industries and metabolized in the body. Its functions are antioxidative, anti-tumor, anti-cancer and have inhibitory effects on colon carcinogenesis in the human body (Shaha et al., 2013). Therefore, bell pepper fruits with high capsanthin content are preferred. Ascorbic acid (Vitamin C) has unique antioxidant properties and also strengthens the immune system of the body against diseases.

TSS in bell pepper are of great importance from processing point of view as bell pepper having TSS $3.3^{\circ}$ Brix or higher are always desired in the processing industries for the preparation of different processed products. DPCBWR-14-3 had maximum TSS (5.00
${ }^{\circ}$ Brix) followed by DPCBWR-14-6 (4.73 ${ }^{\circ}$ Brix) and DPCBWR-14-23 (4.70 ${ }^{\circ}$ Brix). Besides, highest yielder genotypes DPCBWR14-36 and DPCBWR-14-35 also exhibited excellent quality traits viz., ascorbic acid (113.55 mg/100g) and TSS (4.23 ${ }^{\circ}$ Brix). These results are in close confirmity with those of earlier workers for TSS (Islam and Singh 2006 and Afroza et al., 2013a, Sharma et al., 2017 and Thakur et al., 2019), capsanthin (Choudhary et al., 2011, Kumar 2013, Vijaya et al., 2014, Sharma et al., 2017 and Thakur et al., 2019) and ascorbic acid (Sharma et al., 2013, Sharma 2014, Kumar et al., 2015b, Sharma et al., 2017, Esho 2018 and Thakur et al., 2019).

\section{Parameters of variability}

\section{Coefficient of variation}

For formulating an efficient breeding programme, the nature and extent of genetic variability is one of the important criteria and knowledge of PCV and GCV is very much helpful in predicting the amount of variation present in the given set of genetic stocks. The estimates of PCV were higher than corresponding GCV for all the characters studied (Table 5) which indicated that the apparent variation is not only due to genotypes but also due to the influence of environment. However, the differences between the genotypic and phenotypic variances were relatively low for all the traits studied. This indicated highly heritable and comparatively stable nature of the characters and thus, the selection based on phenotypic performance would be quite effective in the improvement of these traits. Afroza et al., (2013b), Pandey et al., (2013), Rana et al., (2015), Sharma et al., (2017), Thakur et al., (2017), Aditika et al., (2018), Singh et al., (2018), Esho (2018), Sharma et al., (2019) and Thakur et al., (2019) also found high PCV than the corresponding GCV in their respective studies. 
The magnitude of PCV and GCV were high for marketable fruit yield per plant, marketable fruits per plant and capsanthin content (Table 5). These high estimates indicated that there is substantial variability ensuring ample scope for improvement of these traits through selection. Sharma et al., (2017) and Thakur et al., (2019) have reported high PCV and GCV for marketable fruit yield per plant, marketable fruits per plant and capsanthin content. Singh et al., (2018) also reported high PCV and GCV value for marketable fruits per plant and marketable fruit yield per plant.

The moderate estimates of PCV and GCV were recorded for plant height, harvest duration, fruit length, pericarp thickness, lobes per fruit, average fruit weight, TSS and ascorbic acid. The moderate estimates suggested cautions approach while following direct selection for these traits.

Such moderate estimates have also been reported by earlier research workers for plant height (Ahmed et al., 2012; Thakur et al., 2017; Aditika et al., 2018, Singh et al., 2018 and Thakur et al., 2019), harvest duration, lobes per fruit and pericarp thickness (Sood et al., 2011 and Thakur et al., 2019), fruit length (Sood et al., 2011; Ahmed et al., 2012; Kumari, 2013; Pandey et al., 2013; Rana et al., 2015; Thakur et al., 2017 and Singh et al., 2018), average fruit weight (Sharma 2014; Rana et al., 2015; Aditika et al., 2018 and Singh et al., 2018), ascorbic acid (Afroza et al., 2013a) and TSS (Sharma et al., 2017 and Thakur et al., 2019). In contrary of this, moderate PCV and low GCV for plant height and low PCV and GCV for harvest duration and pericarp thickness by Sharma et al., (2017), high PCV and GCV for ascorbic acid by Sharma et al., (2010), low PCV and GCV for pericarp thickness by Thakur et al., (2017), high PCV and GCV for pericarp thickness by Singh et al., (2018), high PCV and GCV for average fruit weight by Kumari (2013) and Thakur et al., (2017), moderate PCV and low GCV for average fruit weight by Thakur et al., (2019) and low PCV and GCV for ascorbic acid content by Singh et al., (2018).

The rest of the traits namely, days to 50 per cent flowering, days to first picking, primary branches per plant and fruit width showed low PCV and GCV estimates (Table 5). These traits can be improved through hybridization. The low estimates have also been reported by Kumar et al., (2015a), Rana et al., (2015), Sharma et al., (2017), Singh et al., (2018) and Thakur et al., (2019) for days to 50 per cent flowering, Sood et al., (2011), Kumar et al., (2015a), Sharma et al., (2017), Singh et al., (2018) and Thakur et al., (2019) for days to first picking, Singh et al., (2018) for number of primary branches and Sharma et al., (2019) for fruit width. In contrary of this, moderate PCV and GCV for primary branches per plant was estimated by Rana et al., (2015), Sharma et al., (2017) and Thakur et al., (2019) and moderate PCV and GCV for fruit width by Rana et al., (2015).

Table.1 Magnitude of differences for parameters

\begin{tabular}{|l|c|c|c|}
\hline & High (\%) & Moderate (\%) & Low (\%) \\
\hline PCV and GCV & $>20$ & $10-20$ & $<10$ \\
\hline Heritability (\%) & $>60$ & $30-60$ & $<30$ \\
\hline Genetic advance & $>30$ & $10-30$ & $<10$ \\
\hline
\end{tabular}


Table.2 List of bell pepper genotypes and their sources

\begin{tabular}{|c|c|c|c|c|c|}
\hline Sr. No. & Genotypes & Source & Sr. No. & Genotypes & Source \\
\hline 1. & DPCBWR-14-1 & $\begin{array}{l}\text { Department of Vegetable Science \& } \\
\text { Floriculture, CSKHPKV, Palampur } \\
\text { (HP) }\end{array}$ & 23. & DPCBWR-14-22 & $\begin{array}{l}\text { Department of Vegetable Science \& } \\
\text { Floriculture, CSK HPKV, Palampur } \\
\text { (HP) }\end{array}$ \\
\hline 2. & DPCBWR-14-2 & - do- & 24. & DPCBWR-14-23 & - do- \\
\hline 3. & DPCBWR-14-3 & - do- & 25. & DPCBWR-14-24 & - do- \\
\hline 4. & DPCBWR-14-4 & - do- & 26. & DPCBWR-14-24-1 & - do- \\
\hline 5. & DPCBWR-14-5 & -do- & 27. & DPCBWR-14-25 & -do- \\
\hline 6. & DPCBWR-14-5-1 & -do- & 28. & DPCBWR-14-28 & -do- \\
\hline 7. & DPCBWR-14-6 & -do- & 29. & DPCBWR-14-29 & -do- \\
\hline 8. & DPCBWR-14-6-1 & - do- & 30. & DPCBWR-14-30 & - do- \\
\hline 9. & DPCBWR-14-7 & -do- & 31. & DPCBWR-14-31 & -do- \\
\hline 10. & DPCBWR-14-7-1 & -do- & 32. & DPCBWR-14-32 & - do- \\
\hline 11. & DPCBWR-14-8-1 & -do- & 33. & DPCBWR-14-35 & -do- \\
\hline 12. & DPCBWR-14-9 & - do- & 34. & DPCBWR-14-36 & -do- \\
\hline 13. & DPCBWR-14-10 & -do- & 35. & DPCBWR-14-38 & -do- \\
\hline 14. & DPCBWR-14-11 & -do- & 36. & DPCBWR-14-39 & -do- \\
\hline 15. & $\begin{array}{l}\text { DPCBWR-14- } \\
11(\mathrm{BS})\end{array}$ & -do- & 37. & DPCBWR-14-40 & -do- \\
\hline 16. & DPCBWR-14-12 & - do- & 38. & L-22 & -do- \\
\hline 17. & DPCBWR-14-13 & -do- & 39. & L-4 & - do- \\
\hline 18. & DPCBWR-14-14 & -do- & 40. & EC-464107 (R)-Check & AVRDC, Taiwan \\
\hline 19. & DPCBWR-14-15 & -do- & 41. & EC-464115 (R)-Check & AVRDC, Taiwan \\
\hline 20. & DPCBWR-14-16 & -do- & 42. & $\begin{array}{l}\text { Kandaghat Selection } \\
\text { (MR)-Check }\end{array}$ & RRS, Kandaghat, UHF, Solan (HP) \\
\hline 21. & DPCBWR-14-17 & - do- & 43. & $\begin{array}{l}\text { California Wonder (S)- } \\
\text { Check }\end{array}$ & $\begin{array}{c}\text { ICAR - IARI Regional Station, } \\
\text { Katrain (Kullu), HP }\end{array}$ \\
\hline 22. & DPCBWR-14-20 & - do- & & & \\
\hline
\end{tabular}


Table.3 Analysis of variance for quantitative and quality traits in bell pepper genotypes

\begin{tabular}{|c|c|c|c|c|}
\hline S. NO. & Sources of variation $\rightarrow$ Traits $\mathrm{df} \rightarrow$ & Replication 2 & Genotypes 42 & Error 84 \\
\hline 1. & Quantitative Traits & & & \\
\hline \multirow[t]{6}{*}{ a) } & Phenological and Structural traits & & & \\
\hline & Days to 50 per cent flowering & 2.20 & $26.22 *$ & 4.20 \\
\hline & Days to first picking & 1.33 & $47.30 *$ & 1.78 \\
\hline & Plant height $(\mathrm{cm})$ & 3.75 & $117.88 *$ & 3.16 \\
\hline & Primary branches per plant & 0.06 & $0.15^{*}$ & 0.02 \\
\hline & Harvest duration (days) & 0.67 & $80.96 *$ & 4.82 \\
\hline \multirow[t]{8}{*}{ b) } & Fruit yield traits & & & \\
\hline & Fruit length $(\mathrm{cm})$ & 0.01 & $1.96^{*}$ & 0.01 \\
\hline & Fruit width $(\mathrm{cm})$ & 0.09 & $0.23 *$ & 0.02 \\
\hline & Pericarp thickness (mm) & 0.02 & $0.52 *$ & 0.03 \\
\hline & Lobes per fruit & 0.02 & $0.47 *$ & 0.02 \\
\hline & Average fruit weight (g) & 0.66 & $59.11 *$ & 4.04 \\
\hline & Marketable fruits per plant & 0.62 & $18.02 *$ & 0.93 \\
\hline & Marketable fruit yield per plant (g) & 1102.01 & $19727.82 *$ & 1403.74 \\
\hline \multirow[t]{4}{*}{ II. } & Quality traits & & & \\
\hline & Capsanthin content (ASTA units) & 6.22 & $1382.05^{*}$ & 4.51 \\
\hline & Total soluble solids $\left({ }^{\circ}\right.$ Brix $)$ & 0.23 & $0.78^{*}$ & 0.04 \\
\hline & Ascorbic acid content $(\mathrm{mg} / 100 \mathrm{~g})$ & 0.53 & $1080.92 *$ & 3.90 \\
\hline
\end{tabular}

*Significant at $5 \%$ level 
Table.4 Estimates of mean values for quantitative and quality traits in bell pepper genotypes

\begin{tabular}{|c|c|c|c|c|c|c|c|c|c|c|c|c|c|c|c|}
\hline \multirow[t]{3}{*}{ Genotypes/Traits } & \multicolumn{12}{|c|}{ Quantitative traits } & \multirow{2}{*}{\multicolumn{3}{|c|}{ Quality traits }} \\
\hline & DFF & DFP & PH & $\begin{array}{l}\text { Itrats } \\
\text { PBP }\end{array}$ & HD & & FW & PT & LPP & raits & & & & & \\
\hline & & & (cm) & & $\begin{array}{l}\text { HD } \\
\text { (days) }\end{array}$ & (cm) & (cm) & $(\mathrm{mm})$ & 20 & (g) & MFPP & $\underset{(\mathrm{g})}{\mathrm{MFPP}}$ & $\begin{array}{c}\text { CC } \\
\text { (ASTA units) }\end{array}$ & $\begin{array}{c}\text { TSS } \\
\text { ('Brix) }\end{array}$ & $\begin{array}{c}\text { AA } \\
(\mathrm{mg} / 100 \mathrm{~g})\end{array}$ \\
\hline DPCBWR-14-1 & 42.00 & 58.00 & 52.31 & 3.10 & 35.00 & 5.10 & 4.35 & 3.77 & 4.00 & 44.07 & 7.25 & 320.05 & 72.38 & 4.60 & 115.54 \\
\hline DPCBWR-14-2 & 39.33 & 54.00 & 54.67 & 2.83 & 43.00 & 4.26 & 4.56 & 3.63 & 3.00 & 35.12 & 12.80 & 448.93 & 78.74 & 3.53 & 85.33 \\
\hline DPCBWR-14-3 & 41.33 & 64.00 & 52.60 & 2.97 & 43.00 & 4.84 & 4.42 & 3.40 & 3.00 & 41.27 & 8.30 & 342.41 & 81.10 & 5.00 & 138.04 \\
\hline DPCBWR-14-4 & 40.00 & 54.00 & 50.73 & 3.03 & 43.00 & 5.82 & 3.81 & 4.23 & 2.87 & 30.87 & 7.20 & 222.48 & 85.33 & 4.23 & 72.41 \\
\hline DPCBWR-14-5 & 41.00 & 64.33 & 70.00 & 2.97 & 43.00 & 5.31 & 4.05 & 3.57 & 3.00 & 32.80 & 7.50 & 246.36 & 111.55 & 4.47 & 69.35 \\
\hline DPCBWR-14-5-1 & 44.33 & 59.33 & 58.33 & 2.83 & 36.50 & 4.84 & 3.99 & 3.70 & 3.32 & 30.37 & 7.90 & 240.43 & 113.49 & 4.27 & 100.13 \\
\hline DPCBWR-14-6 & 41.00 & 54.00 & 51.60 & 3.17 & 43.00 & 4.88 & 4.14 & 3.77 & 3.47 & 32.46 & 12.60 & 406.61 & 125.73 & 4.73 & 96.21 \\
\hline DPCBWR-14-6-1 & 38.00 & 62.00 & 43.20 & 3.10 & 30.00 & 5.60 & 4.31 & 5.13 & 3.00 & 31.80 & 7.10 & 226.55 & 89.94 & 3.00 & 84.66 \\
\hline DPCBWR-14-7 & 37.67 & 56.67 & 46.00 & 3.03 & 43.00 & 5.19 & 4.25 & 3.70 & 3.32 & 41.91 & 8.60 & 360.38 & 106.21 & 3.60 & 106.06 \\
\hline DPCBWR-14-7-1 & 40.00 & 56.67 & 43.40 & 2.97 & 36.50 & 4.17 & 4.12 & 4.37 & 3.40 & 29.69 & 7.80 & 232.32 & 111.13 & 3.60 & 94.48 \\
\hline DPCBWR-14-8-1 & 41.00 & 56.67 & 46.47 & 3.30 & 43.00 & 3.64 & 4.48 & 4.10 & 3.96 & 34.16 & 10.60 & 362.25 & 91.15 & 3.07 & 76.22 \\
\hline DPCBWR-14-9 & 45.33 & 56.67 & 48.60 & 3.23 & 43.00 & 3.73 & 4.58 & 4.43 & 4.11 & 32.03 & 7.80 & 249.68 & 80.23 & 3.80 & 117.01 \\
\hline DPCBWR-14-10 & 44.33 & 56.67 & 52.73 & 3.03 & 38.67 & 5.66 & 4.29 & 3.60 & 3.58 & 33.47 & 9.30 & 311.74 & 106.13 & 3.60 & 101.36 \\
\hline DPCBWR-14-11 & 43.00 & 56.67 & 52.40 & 3.03 & 43.00 & 4.54 & 4.20 & 4.10 & 3.07 & 30.74 & 10.80 & 331.37 & 143.83 & 3.53 & 104.48 \\
\hline DPCBWR-14-11(BS) & 45.00 & 56.67 & 68.33 & 3.23 & 38.67 & 4.72 & 4.69 & 3.37 & 3.25 & 30.98 & 8.80 & 273.32 & 84.43 & 4.00 & 79.04 \\
\hline DPCBWR-14-12 & 43.00 & 61.00 & 55.00 & 3.08 & 39.00 & 5.07 & 4.41 & 2.97 & 3.63 & 33.84 & 8.60 & 291.30 & 79.94 & 3.80 & 81.22 \\
\hline DPCBWR-14-13 & 41.00 & 55.00 & 38.80 & 2.80 & 41.00 & 4.36 & 4.44 & 3.80 & 3.62 & 34.79 & 11.45 & 398.52 & 93.49 & 3.20 & 97.15 \\
\hline DPCBWR-14-14 & 43.33 & 56.67 & 45.01 & 3.25 & 43.00 & 6.50 & 4.37 & 3.27 & 2.92 & 46.08 & 7.60 & 350.33 & 80.31 & 4.47 & 84.65 \\
\hline DPCBWR-14-15 & 42.33 & 56.67 & 60.40 & 3.17 & 43.00 & 4.71 & 4.29 & 3.50 & 3.33 & 37.13 & 10.00 & 371.33 & 146.24 & 3.60 & 105.52 \\
\hline DPCBWR-14-16 & 48.00 & 56.67 & 46.33 & 2.77 & 45.32 & 5.21 & 4.08 & 4.17 & 2.92 & 36.49 & 8.60 & 314.38 & 123.64 & 3.53 & 101.18 \\
\hline DPCBWR-14-17 & 41.67 & 54.00 & 54.67 & 3.03 & 43.00 & 5.16 & 4.35 & 3.57 & 3.00 & 43.02 & 7.00 & 301.67 & 89.94 & 3.07 & 107.37 \\
\hline DPCBWR-14-20 & 47.67 & 54.00 & 61.53 & 3.10 & 43.00 & 3.75 & 4.92 & 3.77 & 3.00 & 38.24 & 7.70 & 295.57 & 67.56 & 3.33 & 91.02 \\
\hline DPCBWR-14-22 & 46.33 & 69.00 & 52.27 & 2.97 & 46.26 & 4.89 & 4.11 & 4.70 & 3.73 & 31.85 & 9.42 & 299.83 & 94.24 & 3.53 & 109.07 \\
\hline DPCBWR-14-23 & 42.67 & 56.67 & 53.47 & 3.03 & 43.00 & 6.43 & 4.16 & 3.57 & 2.17 & 34.14 & 10.50 & 358.51 & 85.35 & 4.70 & 72.43 \\
\hline DPCBWR-14-24 & 41.00 & 54.00 & 55.00 & 3.10 & 43.00 & 4.87 & 4.39 & 3.83 & 3.00 & 34.46 & 9.00 & 310.61 & 85.76 & 3.80 & 117.37 \\
\hline DPCBWR-14-24-1 & 44.33 & 54.00 & 51.75 & 3.25 & 43.00 & 5.09 & 4.44 & 3.77 & 2.89 & 33.15 & 11.87 & 393.37 & 91.41 & 4.60 & 98.92 \\
\hline DPCBWR-14-25 & 42.00 & 56.67 & 57.53 & 3.43 & 43.00 & 4.30 & 4.17 & 3.97 & 3.33 & 32.47 & 10.90 & 354.43 & 85.82 & 3.47 & 104.48 \\
\hline DPCBWR-14-28 & 42.67 & 56.67 & 53.27 & 3.17 & 43.00 & 4.81 & 4.32 & 3.83 & 3.00 & 26.67 & 11.40 & 305.36 & 109.43 & 3.40 & 65.55 \\
\hline DPCBWR-14-29 & 36.67 & 51.00 & 54.20 & 3.37 & 43.00 & 4.52 & 4.54 & 3.77 & 3.17 & 41.51 & 10.13 & 421.49 & 89.32 & 3.20 & 61.09 \\
\hline DPCBWR-14-30 & 45.67 & 54.00 & 47.67 & 3.03 & 43.00 & 5.18 & 4.18 & 3.90 & 2.64 & 34.74 & 11.10 & 385.58 & 137.67 & 3.50 & 102.72 \\
\hline DPCBWR-14-31 & 43.33 & 54.00 & 50.60 & 2.63 & 43.00 & 5.42 & 4.38 & 3.97 & 3.00 & 35.51 & 11.20 & 394.29 & 95.53 & 3.20 & 124.41 \\
\hline DPCBWR-14-32 & 35.00 & 64.00 & 49.25 & 3.32 & 43.00 & 5.17 & 4.22 & 3.83 & 3.10 & 30.47 & 12.80 & 390.30 & 149.53 & 3.20 & 109.18 \\
\hline DPCBWR-14-35 & 42.33 & 66.67 & 53.07 & 3.15 & 43.00 & 5.25 & 3.92 & 3.57 & 3.00 & 30.42 & 13.93 & 424.34 & 69.94 & 4.23 & 59.13 \\
\hline DPCBWR-14-36 & 43.00 & 56.67 & 62.20 & 3.23 & 38.67 & 4.35 & 4.30 & 3.83 & 3.22 & 31.74 & 16.07 & 510.30 & 76.15 & 3.80 & 113.55 \\
\hline DPCBWR-14-38 & 42.00 & 60.33 & 55.57 & 3.15 & 43.00 & 4.30 & 4.26 & 4.17 & 3.56 & 34.05 & 7.70 & 262.93 & 81.12 & 3.60 & 106.08 \\
\hline DPCBWR-14-39 & 34.50 & 52.00 & 53.87 & 3.10 & 49.67 & 4.46 & 4.30 & 4.10 & 3.07 & 35.35 & 15.33 & 541.44 & 85.47 & 3.40 & 97.15 \\
\hline DPCBWR-14-40 & 41.33 & 54.00 & 59.33 & 3.83 & 43.00 & 4.40 & 4.35 & 4.37 & 3.56 & 31.16 & 12.20 & 380.67 & 130.46 & 3.47 & 130.29 \\
\hline Line-22 & 47.00 & 60.33 & 49.00 & 3.03 & 43.00 & 4.31 & 4.88 & 3.83 & 3.52 & 41.19 & 9.20 & 379.68 & 90.36 & 3.80 & 82.39 \\
\hline Line-4 & 42.00 & 61.67 & 50.00 & 3.70 & 30.00 & 5.20 & 4.43 & 3.50 & 3.50 & 26.56 & 9.52 & 253.50 & 70.52 & 4.00 & 69.04 \\
\hline EC-464107 (R) & 42.00 & 54.00 & 58.00 & 3.17 & 45.33 & 6.81 & 3.53 & 3.30 & 3.20 & 33.14 & 10.20 & 338.50 & 83.98 & 4.20 & 107.36 \\
\hline EC-464115 (R) & 43.33 & 54.00 & 57.33 & 3.43 & 43.00 & 7.77 & 3.55 & 3.23 & 2.33 & 33.54 & 8.70 & 292.72 & 91.43 & 3.53 & 110.99 \\
\hline Kandaghat Selection (MR) & 44.67 & 54.00 & 53.00 & 3.10 & 43.00 & 4.78 & 4.37 & 4.50 & 3.33 & 33.23 & 10.13 & 337.52 & 113.49 & 3.22 & 123.57 \\
\hline California Wonder (S) & 41.33 & 56.67 & 44.87 & 3.23 & 17.67 & 5.33 & 3.96 & 3.67 & 3.67 & 30.91 & 2.90 & 90.32 & 104.24 & 3.60 & 109.18 \\
\hline $\mathrm{SE}(\mathbf{m}) \pm$ & 1.18 & 0.77 & 1.03 & 0.08 & 1.27 & 0.06 & 0.07 & 0.10 & 0.09 & 1.16 & 0.56 & 21.63 & 1.23 & 0.11 & 1.14 \\
\hline $\mathrm{SE}(\mathbf{d}) \pm$ & 1.67 & 1.09 & 1.45 & 0.12 & 1.79 & 0.09 & 0.11 & 0.14 & 0.13 & 1.64 & 0.79 & 30.59 & 1.74 & 0.16 & 1.61 \\
\hline C.V. (\%) & 4.86 & 2.33 & 3.36 & 4.60 & 5.33 & 2.14 & 3.01 & 4.31 & 4.88 & 5.85 & 9.87 & 11.25 & 2.18 & 5.21 & 2.03 \\
\hline C.D. $(\mathrm{P} \leq 0.05)$ & 3.33 & 2.17 & 2.89 & 0.23 & 3.57 & 0.17 & 0.21 & 0.27 & 0.26 & 3.27 & 1.57 & 60.94 & 3.46 & 0.32 & 3.21 \\
\hline Range & 34.50-48.00 & $\begin{array}{l}51.00- \\
69.00\end{array}$ & $\begin{array}{l}38.80- \\
70.00\end{array}$ & 2.63-3.83 & $17.67-49.67$ & 3.64-7.77 & $3.53-4.92$ & $2.97-5.13$ & $2.17-4.11$ & $26.56-46.08$ & $2.90-16.07$ & $90.32-541.44$ & 67.56-149.53 & $3.00-5.00$ & 59.13-138.04 \\
\hline Grand mean & 42.17 & 57.23 & 52.89 & 3.13 & 41.22 & 4.99 & 4.28 & 3.84 & 3.23 & 34.36 & 9.76 & 333.11 & 97.30 & 3.76 & 97.27 \\
\hline
\end{tabular}

$\mathrm{DFF}=$ Days to 50 per cent flowering, $\mathrm{DFP}=$ Days to first picking, $\mathrm{PH}=$ Plant height, $\mathrm{PBP}=$ Primary branches per plant, $\mathrm{HD}=\mathrm{H}$ arvest duration, $\mathrm{FL}=$

Fruit length, FW = Fruit width, PT = Pericarp thickness, LPF = Lobes per fruit, AFW = Average fruit weight, MFPP = Marketable fruits per plant, MFYP = Marketable fruit yield per plant, $\mathrm{CC}=$ Capsanthin content, TSS $=$ Total soluble solids, AA = Ascorb ic acid content 
Table.5 Estimates of genetic parameters for quantitative and quality traits in bell pepper genotypes

\begin{tabular}{|c|c|c|c|c|c|c|c|}
\hline $\begin{array}{l}\text { S. } \\
\text { NO. }\end{array}$ & Traits & $\begin{array}{l}\text { Grand Mean } \pm \\
\text { S.E. }(\mathrm{m})\end{array}$ & Range & PCV (\%) & GCV (\%) & $h^{2}(\%)$ & GA as \% of mean \\
\hline 1. & Quantitative Traits & & & & & & \\
\hline \multirow[t]{6}{*}{ a) } & $\begin{array}{l}\text { Phenological and } \\
\text { Structural traits }\end{array}$ & & & & & & \\
\hline & $\begin{array}{l}\text { Days to } 50 \text { per cent } \\
\text { flowering }\end{array}$ & $42.17 \pm 1.18$ & $34.50-48.00$ & $8.05(\mathrm{~L})$ & $6.42(\mathrm{~L})$ & $63.61(\mathrm{H})$ & $10.55(\mathrm{M})$ \\
\hline & Days to first picking & $57.23 \pm 0.77$ & $51.00-69.00$ & $7.20(\mathrm{~L})$ & $6.81(\mathrm{~L})$ & $89.51(\mathrm{H})$ & $13.27(\mathrm{M})$ \\
\hline & Plant height $(\mathrm{cm})$ & $52.89 \pm 1.03$ & $38.80-70.00$ & $12.16(\mathrm{M})$ & $11.69(\mathrm{M})$ & $92.36(\mathrm{H})$ & $23.15(\mathrm{M})$ \\
\hline & Primary branches per plant & $3.13 \pm 0.08$ & $2.63-3.83$ & $8.01(\mathrm{~L})$ & $6.56(\mathrm{~L})$ & $67.01(\mathrm{H})$ & $11.06(\mathrm{M})$ \\
\hline & Harvest duration (days) & $41.22 \pm 1.27$ & $17.67-49.67$ & $13.33(\mathrm{M})$ & $12.24(\mathrm{M})$ & $84.04(\mathrm{H})$ & $23.08(\mathrm{M})$ \\
\hline \multirow[t]{8}{*}{ b) } & Fruit yield traits & & & & & & \\
\hline & Fruit length $(\mathrm{cm})$ & $4.99 \pm 0.06$ & $3.64-7.77$ & $16.26(\mathrm{M})$ & $16.12(\mathrm{M})$ & $98.28(\mathrm{H})$ & $32.93(\mathrm{H})$ \\
\hline & Fruit width $(\mathrm{cm})$ & $4.28 \pm 0.07$ & $3.53-4.92$ & $6.93(\mathrm{~L})$ & $6.24(\mathrm{~L})$ & $81.19(\mathrm{H})$ & $11.58(\mathrm{M})$ \\
\hline & Pericarp thickness (mm) & $3.84 \pm 0.10$ & $2.97-5.13$ & $11.38(\mathrm{M})$ & $10.54(\mathrm{M})$ & $85.70(\mathrm{H})$ & $20.10(\mathrm{M})$ \\
\hline & Lobes per fruit & $3.23 \pm 0.09$ & 2.17- 4.11 & $12.93(\mathrm{M})$ & $11.97(\mathrm{M})$ & $85.74(\mathrm{H})$ & $22.84(\mathrm{M})$ \\
\hline & Average fruit weight $(\mathrm{g})$ & $34.36 \pm 1.16$ & $26.56-46.08$ & $13.77(\mathrm{M})$ & $12.47(\mathrm{M})$ & $81.96(\mathrm{H})$ & $23.25(\mathrm{M})$ \\
\hline & Marketable fruits per plant & $9.76 \pm 0.56$ & $2.90-16.07$ & $26.38(\mathrm{H})$ & $24.46(\mathrm{H})$ & $85.99(\mathrm{H})$ & $46.73(\mathrm{H})$ \\
\hline & $\begin{array}{l}\text { Marketable fruit yield per } \\
\text { plant }(\mathrm{g})\end{array}$ & $333.11 \pm 21.63$ & $\begin{array}{l}90.32- \\
541.44\end{array}$ & $26.02(\mathrm{H})$ & $23.46(\mathrm{H})$ & $81.31(\mathrm{H})$ & $43.58(\mathrm{H})$ \\
\hline \multirow[t]{4}{*}{ II. } & Quality traits & & & & & & \\
\hline & $\begin{array}{l}\text { Capsanthin content } \\
\text { (ASTA units) }\end{array}$ & $97.30 \pm 1.23$ & $\begin{array}{l}67.56- \\
149.53\end{array}$ & $22.13(\mathrm{H})$ & $22.02(\mathrm{H})$ & $99.03(\mathrm{H})$ & $45.15(\mathrm{H})$ \\
\hline & $\begin{array}{l}\text { Total soluble solids } \\
\left({ }^{\circ} \mathrm{Brix}\right)\end{array}$ & $3.76 \pm 0.11$ & $3.00-5.00$ & $14.26(\mathrm{M})$ & $13.27(\mathrm{M})$ & $86.64(\mathrm{H})$ & $25.45(\mathrm{M})$ \\
\hline & $\begin{array}{l}\text { Ascorbic acid content } \\
(\mathrm{mg} / 100 \mathrm{~g})\end{array}$ & $97.27 \pm 1.14$ & $\begin{array}{l}59.13- \\
138.04\end{array}$ & $19.59(\mathrm{M})$ & $19.48(\mathrm{M})$ & 98.93(H) & $39.91(\mathrm{H})$ \\
\hline
\end{tabular}

$\mathrm{PCV}=$ Phenotypic coefficient of variation, $\mathrm{GCV}=$ Genotypic coefficient of variation, $\mathrm{h}^{2}=$ Heritability, $\mathrm{GA}=$ Genetic Advance, $\mathrm{H}=\mathrm{High}, \mathrm{M}=\mathrm{Medium}, \mathrm{L}=$ Low 
Table.6 Mean performance of top five high yielding genotypes along with check cultivars for quantitative and Quality traits in bell pepper

\begin{tabular}{|c|c|c|c|c|c|c|c|c|c|c|}
\hline $\begin{array}{l}\text { S. } \\
\text { NO. }\end{array}$ & Traits & $\begin{array}{l}\text { California } \\
\text { Wonder } \\
\text { (S) }\end{array}$ & $\begin{array}{c}\text { Kandaghat } \\
\text { Selection } \\
\text { (MR) }\end{array}$ & $\begin{array}{c}\text { EC- } \\
464107 \\
(R)\end{array}$ & $\begin{array}{c}\text { EC- } \\
464115 \\
(R)\end{array}$ & $\begin{array}{c}\text { DPCBWR- } \\
\text { 14-39 }\end{array}$ & $\begin{array}{c}\text { DPCBWR- } \\
14-36\end{array}$ & $\begin{array}{c}\text { DPCBWR- } \\
14-2\end{array}$ & $\begin{array}{c}\text { DPCBWR- } \\
14-35\end{array}$ & $\begin{array}{c}\text { DPCBWR- } \\
14-29\end{array}$ \\
\hline 1. & $\begin{array}{l}\text { Days to } 50 \text { per cent } \\
\text { flowering }\end{array}$ & 41.33 & 44.67 & 42.00 & 43.33 & 34.50 & 43.00 & 39.33 & 42.33 & 36.67 \\
\hline 2. & Days to first picking & 56.67 & 54.00 & 54.00 & 54.00 & 52.00 & 56.67 & 54.00 & 66.67 & 51.00 \\
\hline 3. & Plant height (cm) & 44.87 & 53.00 & 58.00 & 57.33 & 53.87 & 62.20 & 54.67 & 5.3 .07 & 54.20 \\
\hline 4. & $\begin{array}{l}\text { Primary branches per } \\
\text { plant }\end{array}$ & 3.23 & 3.10 & 3.17 & 3.43 & 3.10 & 3.23 & 2.83 & 3.15 & 3.37 \\
\hline 5. & $\begin{array}{l}\text { Harvest duration } \\
\text { (days) }\end{array}$ & 17.67 & 43.00 & 45.33 & 43.00 & 49.67 & 38.67 & 43.00 & 43.00 & 43.00 \\
\hline 6. & Fruit length (cm) & 5.33 & 4.78 & 6.81 & 7.77 & 4.46 & 4.35 & 4.26 & 5.25 & 4.52 \\
\hline 7. & Fruit width (cm) & 3.96 & 4.37 & 3.53 & 3.55 & 4.30 & 4.30 & 4.56 & 3.92 & 4.54 \\
\hline 8. & $\begin{array}{l}\text { Pericarp thickness } \\
(\mathbf{m m})\end{array}$ & 3.67 & 4.50 & 3.30 & 3.23 & 4.10 & 3.83 & 3.63 & 3.57 & 3.77 \\
\hline 9. & Lobes per fruit & 3.67 & 3.33 & 3.20 & 2.33 & 3.07 & 3.22 & 3.00 & 3.00 & 3.17 \\
\hline 10. & $\begin{array}{l}\text { Average fruit weight } \\
\text { (g) }\end{array}$ & 30.91 & 33.23 & 33.14 & 33.54 & 35.35 & 31.74 & 35.12 & 30.42 & 41.51 \\
\hline 11. & $\begin{array}{l}\text { Marketable fruits per } \\
\text { plant }\end{array}$ & 2.90 & 10.13 & 10.20 & 8.70 & 15.33 & 16.07 & 12.80 & 13.93 & 10.13 \\
\hline 12. & $\begin{array}{l}\text { Marketable fruit } \\
\text { yield per plant (g) }\end{array}$ & 90.32 & 337.52 & 338.50 & 292.72 & 541.44 & 510.30 & 448.93 & 424.34 & 421.49 \\
\hline 13. & $\begin{array}{l}\text { Capsanthin content } \\
\text { (ASTA units) }\end{array}$ & 104.24 & 113.49 & 83.98 & 91.43 & 85.47 & 76.15 & 78.74 & 69.94 & 89.32 \\
\hline 14. & TSS ( ${ }^{\mathbf{o} B r i x)}$ & 3.60 & 3.22 & 4.20 & 3.53 & 3.40 & 3.80 & 3.53 & 4.23 & 3.20 \\
\hline 15. & $\begin{array}{l}\text { Ascorbic acid } \\
(\mathrm{mg} / \mathbf{1 0 0 g})\end{array}$ & 109.18 & 123.57 & 107.36 & 110.99 & 97.15 & 113.55 & 85.33 & 59.13 & 61.09 \\
\hline
\end{tabular}




\section{Heritability and genetic advance}

\section{Heritability}

Heritability in broad sense is a parameter of tremendous significance to the breeders as its magnitude indicates the reliability with which a genotype can be recognized by its phenotypic expression. According to Burton and De Vane (1953), heritability is a measure of heritable variation and it is helpful in predicting the expected amount of improvement to be achieved through selection together with genotypic coefficient of variation. The information on heritability estimates is helpful in studying the inheritance of quantitative characters as well as for planning breeding programmes with desired degree of expected general progress.

In the present study, high heritability (>60\%) estimates were recorded for all the traits. The heritability estimates (Table 5) were recorded to be high for capsanthin content (99.03\%), ascorbic acid (98.93\%), fruit length (98.28\%), plant height $(92.36 \%)$, days to first picking $(89.51 \%)$, TSS $(86.64 \%)$, marketable fruits per plant (85.99\%), lobes per fruit (85.74\%), pericarp thickness $(85.70 \%)$, harvest duration $(84.04 \%)$, average fruit weight $(81.96 \%)$, marketable fruit yield per plant $(81.31 \%)$, fruit width $(81.19 \%)$, days to 50 per cent flowering $(63.61 \%)$ and primary branches per plant $(67.01 \%)$ indicating that these traits were less influenced by environment. This suggested that large proportion of phenotypic variation has been attributed to the genotypic variance and hence, reliable selection could be made for these traits on the basis of phenotypic expression.

Higher estimates of heritability had also been reported by earlier workers for ascorbic acid and harvest duration (Aditika et al., 2018; Sharma et al., 2019 and Thakur et al., 2019), fruit length (Sood et al., 2011; Ahmed et al.,
2012; Sharma et al., 2017; Singh et al., 2018; Sharma et al., 2019 and Thakur et al., 2019), TSS (Afroza et al., 2013a; Sharma et al., 2017 and Thakur et al., 2019), pericarp thickness (Aditika et al., 2018; Singh et al., 2018; Sharma et al., 2019 and Thakur et al., 2019), marketable fruit yield per plant (Sharma et al., 2017; Singh et al., 2018 and Thakur et al., 2019), primary branches per plant (Aditika et al., 2018 and Thakur et al., 2019), lobes per fruit (Aditika et al., 2018; Sharma et al., 2019 and Thakur et al., 2019), plant height (Kumari 2013; Rana et al., 2015; Aditika et al., 2018; Singh et al., 2018; Sharma et al., 2019 and Thakur et al., 2019), days to 50 per cent flowering (Rana et al., 2015; Aditika et al., 2018; Singh et al., 2018 and Thakur et al., 2019) and days to first picking (Singh et al., 2018 and Thakur et al., 2019), average fruit weight (Kumari 2013; Aditika et al., 2018 and Sharma et al., 2019), capsanthin content and marketable fruits per plant (Thakur et al., 2019), fruit width (Kumari 2013; Singh et al., 2018 and Sharma et al., 2019) and marketable fruits per plant (Singh et al., 2018). In contrary, moderate heritability for average fruit weight and TSS and low for ascorbic acid was noticed by Singh et al., (2018). Low heritability for pericarp thickness, days to 50 per cent flowering and days to first picking and moderate for plant height, primary branches per plant and lobes per fruit by Sharma et al., (2017) and moderate heritability for average fruit weight by Thakur et al., (2019).

\section{Genetic advance}

The results revealed that the response to selection for different characters which showed high heritability needs to be given due emphasis for effective selection as these characters were under genetic control. However, the high heritability does not necessarily mean high genetic gain and is not sufficient alone to make improvement through 
simple phenotypic selection. The heritability estimates are more beneficial when used to estimate genetic advance (Johnson et al., 1955) and hence, the genetic advance provides an edge over heritability as a guiding factor to breeders in various selection programmes.

Genetic advance as per cent of mean (Table 5) was observed to be high for marketable fruits per plant $(46.73 \%)$, capsanthin content $(45.15 \%), \%)$, marketable fruit yield per plant (43.58\%), ascorbic acid (39.91) and fruit length $(32.93 \%)$. Such high estimates of genetic advance have also been reported by Thakur et al., (2019) for ascorbic acid content, Singh et al., (2018) and Thakur et al., (2019) for marketable fruits per plant and marketable fruit yield per plant, Thakur et al., (2019) for capsanthin content, Sood et al., (2011) and Thakur et al., (2017) for fruit length. In contrary, Thakur et al., (2019) also reported moderate genetic advance for fruit length.

The moderate expected genetic advance expressed as per cent of mean was observed for TSS (25.45\%), average fruit weight $(23.25 \%)$, plant height $(23.15 \%)$, harvest duration $(23.08 \%)$, lobes per fruit $(22.84 \%)$, pericarp thickness (20.10\%), days to first picking (13.27\%), fruit width (11.58\%), primary branches per plant $(11.06 \%)$ and days to 50 per cent flowering $(10.55 \%)$. Earlier workers have also reported moderate genetic advance for pericarp thickness (Sood et al., 2011; Aditika et al., 2018 and Sharma et al., 2019), fruit width (Rana et al., 2015 and Sharma et al., 2019), plant height (Thakur et al., 2017; Sharma et al., 2019 and Thakur et al., 2019), primary branches per plant (Sharma et al., 2017; Singh et al., 2018 and Thakur et al., 2019), lobes per fruit (Sood et al., 2011; Aditika et al., 2018; Sharma et al., 2019 and Thakur et al., 2019), average fruit weight (Rana et al., 2015; Singh et al., 2018 and Thakur et al., 2019) and for harvest duration, days to first picking and days to 50 per cent flowering by (Thakur et al., 2019). In contrary, low genetic advance for plant height and pericarp thickness was reported by (Thakur et al., 2017). Low estimates of genetic advance have been reported by Kumari (2013); Kumar et al., (2015a); Thakur et al., (2017) and Thakur et al., (2019) for fruit width. High estimates of genetic advance have also been reported by Singh et al., (2018) for pericarp thickness.

For an effective selection programme, knowledge of estimates of heritability alone is not sufficient and it is therefore useful to study genetic advance along with heritability. Genetic advance may or may not be in proportion to genetic variability and heritability estimates because both high estimates of heritability and genetic variability are important to obtain higher genetic gain.

High heritability along with high genetic advance was observed for marketable fruit yield per plant, marketable fruits per plant, fruit length, capsanthin content and ascorbic acid (Table 5). The results suggested the importance of additive gene action for the inheritance of these characters. Thus, improvement can be brought about by phenotypic selection for these characters. Earlier researchers have also found similar results for marketable fruit yield per plant (Singh et al., 2018 and Thakur et al., 2019), marketable fruits per plant (Singh et al., 2018 and Thakur et al., 2019), ascorbic acid content and capsanthin content (Thakur et al., 2019) and fruit length (Thakur et al., 2017). In contrary, ascorbic acid (Kumar et al., 2015a) showed high heritability coupled with moderate genetic advance.

High heritability coupled with moderate genetic advance for days to 50 per cent 
flowering, days to first picking, plant height, primary branches per plant, harvest duration, fruit width, pericarp thickness and lobes per fruit, average fruit weight and TSS (Table 5) indicates preponderance of additive gene action which implies that these traits can be improved through pure line selection. Similar results have also been observed for plant height by (Singh et al., 2018 and Thakur et al., 2019), primary branches per plant (Thakur et al., 2019), fruit width (Rana et al., 2015 and Singh et al., 2018), pericarp thickness and lobes per fruit (Sood et al., 2011; Aditika et al., 2018; Sharma et al., 2019 and Thakur et al., 2019), days to 50 per cent flowering, days to first picking and harvest duration (Thakur et al., 2019) and average fruit weight (Sood et al., 2011; Rana et al., 2015 and Sharma et al., 2019)

There was sufficient genetic variability within the germplasm of bell pepper evaluated for the improvement of quantitative and quality traits. The genetic variation observed suggests that a positive response to direct selection is possible for marketable fruit yield per plant, marketable fruits per plant and capsanthin content as these traits showed high PCV, GCV, heritability and genetic advance.

\section{References}

Aditika, Kanwar HS, Kumar R, Dogra RK, Sharma R and Singh S. 2018. Genetic parameters for yield and yield components in $\mathrm{F}_{1}$ hybrids and parents of bell pepper. International Journal of Current Microbiology and Applied Sciences 7(3): 2669-2673.

Afroza B, Khan SH, Chattoo MA, Mufti S, Parveen K and Mukhdoomi MI. 2013a. Variability studies for quality traits in sweet pepper (Capsicum annuum L.). The Asian Journal of Horticulture 8: 358-360.

Afroza B, Khan SH, Mushtaq F, Hussain K and Nabi A. 2013b. Variability and correlation studies in sweet pepper (Capsicum annuum L.). Progressive Horticulture 45: 209-213.

Ahmed N, Singh SR, Lal S and Mir KA. 2012. Genetic variability in bell pepper (Capsicum annuum L.) under high altitude temperate environment. Indian Journal of Plant Genetic Resources 25: 304-306.

AOAC. 1980. Official methods of analysis of the association of official analytical chemists. (Ed. William Hortwitz). Benzamin Franklin Station, Washington, D.C.

Bukasov SM. 1930. The cultivated plants of Mexico, Guatemala and Columbia. Bulletin of Applied Botanical Genetics and Plant Breeding Supplement 47: 261-273.

Burton GW and De Vane EM. 1953. Estimating heritability in tall fescue (Festuca arundinacea) from replicated clonal material. Agronomy Journal 45: 478-481.

Cebula S, Jakubas A, Sękara A, Kalisz A and Pohl A. 2015. The relationship between morphological features and nutritive value of sweet pepper fruits. Acta Scientiarum Polonorum Hortorum Cultus 14: 79-91.

Choudhary N, Pathania NK, Singh SP, Kumar $P$ and Singh Y. 2011. Evaluation of red and yellow capsicum hybrids for quality attributes in naturally ventilated polyhouse in mid hills of Western Himalayas. Vegetable Science 38: 218220.

Devi J, Sood S, Sagar V and Singh Y. 2015. Inheritance of bacterial wilt resistance and performance of horticultural traits in bell pepper (Capsicum annuum var. grossum). Indian Journal of Agricultural Sciences 85: 1498-1503.

Esho KM. 2018. Genetic analysis in some varieties of pepper (Capsicum annuum 
L.). International Journal of Science and Research 8(5): 796-799.

Hasler CM. 1998. Functional foods. Their role in disease prevention and health. Journal of Food Technology 52: 63-69.

Islam S and Singh RV. 2006. Variability, heritability and genetic advance studies in sweet pepper (Capsicum annuum L.). Indian Journal of Plant Genetic Resources 19: 203-205.

Johnson HW, Robinson HF and Comstock RE. 1955. Estimates of genetic and environmental variability in soybean. Agronomy Journal 47: 314-318.

Kumar V, Pathania NK and Devi M. 2015a. Genetic diversity assessment in green and coloured bell pepper (Capsicum annuum L.) in naturally ventilated quonset polyhouse. Research in Environment and Life Sciences 8: 595598.

Kumar V, Pathania NK and Kumar N. 2015b. Evaluation of bell pepper (Capsicum anпиum L. var. grossum Sendt.) genotypes for quality traits in modified naturally ventilated polyhouse. Asian Journal of Plant Science and Research 5: 35-37.

Kumar V. 2013. Evaluation of bell pepper (Capsicum annuum L. var. grossum Sendt.) hybrids in modified naturally ventilated Quonset polyhouse. M.Sc. Thesis, p 83. Department of Vegetable Science and Floriculture, CSK Himachal Pradesh Krishi Vishvavidyalaya, Palampur, India

Kumari S. 2013. Genetic variability studies in bell pepper (Capsicum annuum L.). The Asian Journal of Horticulture 8: 280284.

Opstat. Computer programming for data analysis. hau.ernet.in

Pandey V, Chura A, Arya MC and Ahmed Z. 2013. Variability parameters for quantitative and qualitative traits in sweet pepper in mid hills of Western
Himalaya. Vegetable Science 40: 37-39. Panse VG and Sukhatme PV. 1984. Statistical Methods for Agricultural Workers. Indian Council of Agricultural Research, New Delhi. p 359.

Purseglove JW, Brown EG, Green CL and Robins SRJ. 1981. Spices. I ${ }^{\text {st }}$ Edu, Longman Inc., New York, USA. p 331.

Rana M, Sharma R, Sharma P, Bhardwaj SV, Kumar S, Brar NS, Sharma M and Dogra R. 2015. Studies on genetic variability and divergence in Capsicum for fruit yield and quality traits in North-Western Himalayas. Ecology, Environment and Conservation 21: 415421.

Ranganna S. 1977. Manual of analysis of fruits and vegetables products. Tata Mc Graw Hill Book Company, New Delhi. p 634.

Rios AKB, Juarez LAM, Aguilar GAG and Meza NG. 2013. Antioxidant activity of the phenolic and oily fractions of different sweet bell peppers. Journal of Mexican Chemical Society 57: 137-143.

Robinson HF, Comstock RE and Harvey PH. 1949. Estimates of heritability and degree of dominance in corn. Agronomy Journal 41: 253-259.

Shaha RK, Rahman S and Asrul A. 2013. Bioactive compounds in chilli pepper (Capsicum annuum L.) at various ripening (green, yellow and red) stages. Annals of Biological Research 4(8): 2734.

Sharma A, Kumar M, Dogra RK, Kumar N, Kumari R and Kansal S. 2019. Estimation of genetic variability in bell pepper (Capsicum annuum L. var. grossum). International Journal of Chemical Studies 7(3): 10-13.

Sharma A. 2014. Studies on genetic divergence in bell pepper (Capsicum annuum L. var. grossum). M.Sc. Thesis, p 63. Department of Vegetable Science, Dr. YS Parmar University of 
Horticulture and Forestry, Nauni, Solan, India

Sharma V, Sood S, Sood VK and Singh Y. 2017. Genetic variation, association of characters and their contribution for improvement in bell pepper (Capsicum anпиит L. var. grossum Sendt.). Himachal Journal of Agricultural Research 43(2): 78-88.

Sharma VK, Punetha S and Sharma BB. 2013. Heterosis studies for earliness, fruit yield and yield attributing traits in bell pepper. African Journal of Agricultural Research 8: 4088-4098.

Sharma VK, Semwal CS and Uniyal SP. 2010. Genetic variability and character association analysis in bell pepper (Capsicum annuum L.). Journal of Horticulture and Forestry 2(3): 058065.

Singh Y, Thakur R and Sekhon BS. 2018. Genetic variability among bacterial wilt resistant genotypes of sweet pepper for yield and morpho-physiological traits under mid hill conditions of North Western Himalayas. Vegetable Science 45(1): 109-115.

Sood S, Kumar N, Chandel KS and Sharma P. 2011. Determination of genetic variation for morphological and yield traits in bell pepper (Capsicum annuum var. grossum). Indian Journal of Agricultural Sciences 81(7): 590-594.

Sood S, Sood R, Sagar V and Sharma KC. 2009. Genetic variation and association analysis for fruit yield, agronomic and quality characters in bell pepper. International Journal of Vegetable Science 15: 272-284.

Thakur M, Sood S and Gupta N. 2019. Genetic analysis of quantitative and quality traits in bacterial wilt resistant genotypes of bell pepper under subtemperate conditions of North-Western Himalayas. Journal of Pharmacognosy and Phytochemistry 1: 66-73.

Thakur S, Thakur R and Mehta DK. 2017. Evaluation of genotypes of bell pepper (Capsicum annuum L.) in cold desert zone of Tabo valley of Spiti district of Himachal Pradesh. International Journal of Agricultural Sciences 13: 3033.

Vijaya HM, Gowda APM and Nehru SD. 2014. Genetic variability, correlation coefficient and path analysis in chilli (Capsicum annuum L.) genotypes. Research in Environment and Life Sciences 7: 175-178.

\section{How to cite this article:}

Anuradha and Sonia Sood. 2019. Genetic Assessment for Fruit Yield and Horticultural Traits in Bacterial Wilt Tolerant Genotypes of Bell Pepper (Capsicum аппиит L. var. grossum Sendt.). Int.J.Curr.Microbiol.App.Sci. 8(08): 872-888. doi: https://doi.org/10.20546/ijcmas.2019.808.101 